\title{
The Ecological Sports Tourism Tourists Behavior Investigation-The Case of Liuxi River National Forest Park in Guangzhou
}

\author{
Peiqi Li \\ Management School, Jinan University, Guangzhou, China \\ Email:350482432@qq.com
}

How to cite this paper: Li, P. Q. (2017). The Ecological Sports Tourism Tourists Behavior Investigation-The Case of Liuxi River National Forest Park in Guangzhou. Chinese Studies, 6, 132-142.

https://doi.org/10.4236/chnstd.2017.62012

Received: March 20, 2017

Accepted: May 23, 2017

Published: May 26, 2017

Copyright $\odot 2017$ by author and Scientific Research Publishing Inc. This work is licensed under the Creative Commons Attribution International License (CC BY 4.0).

http://creativecommons.org/licenses/by/4.0/

\section{(c) (i) Open Access}

\begin{abstract}
In recent years, forest park becomes ecological sports tourism tourists' preference travel destination. The article using the questionnaires and factor analysis to analyze the customer behavior motivation of ecology sports tourists in Guangzhou Liuxi river forest park. Based on the research, we can find: after the ornamental tourist motives, sports leisure motivation becomes one of the important motivations of ecological sports tourism tourists. Secondly, ecological sports tourism tourist consumption intention will be obvious, but the consumption level is not high. Thirdly, safety satisfaction is a general level of the ecological sports tourism tourists. The factors that influence tourist motivation and satisfaction degree include the ecological environment, ecological sports tourism facilities, ecological cultural conditions and the ecological sports services. Therefore the paper puts forward some advice to improve the ecological sports tourism theme features of infrastructure, service content and service level.
\end{abstract}

\section{Keywords}

Forest Park, Ecological Sports Tourism, Tourist Behavior, Guangzhou

\section{Introduction}

Ecological sports tourism consumption has a strong plasticity, in the wave of sports tourism; people buy sports products, sports and sports services experience get into the rapid development stage. With the rapid development of tourism, ecological sports tourism has become a research hotspot.

Eco-sports tourism is human beings in the natural environment, such as fitness, cultivate one's morality raises a gender to the principle of an individual or group activities. Connotation and characteristics of ecological sports, develop the sports activities in the natural environment and social and ecological envi- 
ronment (Zheng Xiaoxiang, 2005). Forest Park tourism has been favored as a healthy modern tourism form (Guoxiao Ping et al., 2015), both to carry the natural regulation of the ecosystem, to meet the needs of eco-sports tourists in person, and meet the ecological sports tourists leisure, Sports, health and other functions. On the tourists eco-sports tourism research are: tourist behavior, tourists perception decision-making, visitors will pay, travel destination market segmentation and tourism travel structure (Chen Ke, Li Zhaoxuan, Wang Qiubing, Zhou Rongwei, \& Wu Ke, 2010). Most of the research is tourism destination, and eco-tourism consumer behavior research of tourism destination research is less. Customer satisfaction is an important indicator of the influencing factors of eco-sports tourists' consumption behavior. Tourist satisfaction is the tourist's natural landscape, infrastructure, human environment, service experience and other aspects of tourist destination to meet the tourist needs and tourism needs Comprehensive psychological evaluation. (Zhu Zhi, 2015) investigated the satisfaction of eco-sports tourism tourists and analyzed the motivations of tourists' tourism, to provide reference and reference for the development of ecological sports tourism.

\section{Research Objects and Research Methods}

\subsection{Research Objects}

Liuxi river National Forest Park is located in Conghua northeast of Guangzhou, is one of the first batch of forest parks in China, with a total area of 8831 hectares. Belongs to the subtropical monsoon climate, mild climate throughout the year, abundant rainfall, natural resources, superior conditions to make it in Guangdong Province 5A-class tourist attractions (Chen Lili \& Zhang Jiaen, 2011). Liuxi River National Forest Park have social humanities and forest entertainment functions. There are cruise entertainment, national customs garden, monkey watch, outdoor projects more than 10 amusement projects, The establishment of plum blossom, stream fleeting, rare plant landscape garden 13 cultural landscape, the development of the Wuzhishan area, Lake plank road, San Ya Tong Valley, small Lijiang River, Huangniushan, Emerald Islands, more than 20 natural landscape.

Liuxi river National Forest Park as an important ecological sports tourism scenic spots, analysis tourists eco-sports tourism consumption behavior, enrich market segments of the forest park tourism. This paper chooses the eco-sports tourists' consumption behavior of Liuxi river Forest Park as the research object. Because Liuxi river Forest Park, with unique natural environment and historical humanities, attracts tourists from Guangzhou, Pearl River Delta and even inside and outside the province, especially consumers with a view of Ecological sports tourism. It has important significance and realistic reference to research this area tourist motivation and satisfaction.

\subsection{Research Methods}

Based on the questionnaire survey, the behavioral characteristics of forest park 
eco-sports tourists were investigated in Guangzhou Liuxi river Forest Park. We selected eco-sports tourism as the main purpose for tourists to interview in the Guangzhou Liuxi River Forest Park.

A total of 300 questionnaires were investigated. After the invalid questionnaires were removed, the effective questionnaires were 271 and the effective rate was $90.3 \%$. The main contents include four parts: the first is the basic characteristics of tourists (gender, age, education, occupation, income), the second is the general behavioral characteristics (eco-sports tourism motives, travel, willingness to pay, etc.), the third is general Consumption characteristics (consumption level), the fourth is the tourist perception characteristics (tourism destination attraction analysis, eco-sports tourism tourist satisfaction). Making the eco-sports tourists behavior questionnaire for tourists in the Guangzhou Liuxi River National Forest Park, and used SPSS 18.0 to descriptive analysis and correlation analysis.

\section{Results and Analysis}

\subsection{Basic Demographic Characteristics of Tourists}

Survey data show that eco-sports tourism tourists gender ratio accounted for $56.31 \%$ and $43.69 \%$, male tourists accounted for a higher proportion. Male tourists in the outdoor tourism has a certain advantage, because the male character, physical, social division of labor is more inclined to nature of adventure spirite. therefore, will be more male tourists join in eco-sports tourism. Forest Park Sports tourism involves climbing wading and other physical activities, more suitable for young people to participate.

In the age structure, the largest proportion is 25 - 34 year-old tourists, accounts for 33.98\%; secondly is 16 - 24 years old for $31.06 \%$. 35 - 44-year-old tourists and 45 -year-old tourists accounted for $15.66 \%$ and $12.63 \%$. It shows that the age structure of Liuxi River Forest Park is becoming more and more young, the main is young tourists, they enjoys the experience and irritation. Occupational and income levels reflect the consumption level of tourist destinations, the largest among which the top three occupations are regular staff, students and freelancers, for $34.62 \%, 25.91 \%$ and $12.62 \%$ respectively, accounting for $73.15 \%$, These three types of tourists characterized that a longer leisure time, income between the social average. While the teachers and civil servants were $6.46 \%$ and $9.70 \%$, may be due to high education, high income led to higher levels of tourism consumption. And low attractiveness in this group for forest Park. So lead to fewer visits. Income level is mainly concentrated in the monthly income of 800 2000 yuan, $2001-4000$ yuan, $4001-8000$ yuan, there are respectively is $25.70 \%$, $31.51 \%$ and $21.27 \%$, it is worth noting that the monthly income of less than 800 yuan accounted for $17.13 \%$ While the monthly income of more than 8000 yuan accounted for $4.39 \%$. Explain eco-sports tourism is more popular with the middle and low-income people in the LiuXi river Forest Park. The eco-sports tourism project belongs to the mass consumption. Ecological sports tourism has a strong participation, interaction, while some eco-sports tourism projects need 
high cost and a certain level of aesthetic.

Cultural level and tourism travel structure affect eco-sports tourists behavior. Among them, the highest proportion of high school students and the following qualifications is $41.74 \%$, college is $49.51 \%$, graduate and above is $8.7 \%$. Friends together, and family travel is the most two kinds of popular way o, it is $44.6 \%$ and $30.7 \%$. As shown in Figure 1.

\subsection{Behavior of Eco-Sports Tourists}

The study of tourists "behavior of eco-sports tourists mainly includes tourists" motive behavior, decision-making behavior, travel mode and tourism purchase behavior (Yin Yumei, Lu Yuqi, \& Deng Jitao, 2004). This paper analyzes the behavior characteristics of eco-sports tourists, mainly from the three aspects of tourists' travel motives, travel methods and willingness to pay.

\subsubsection{Tourism Motivation}

The tourists have a psychological expectation, tourism process and the results of the tourist destination. Expectations will affect consumers' tourist motives.
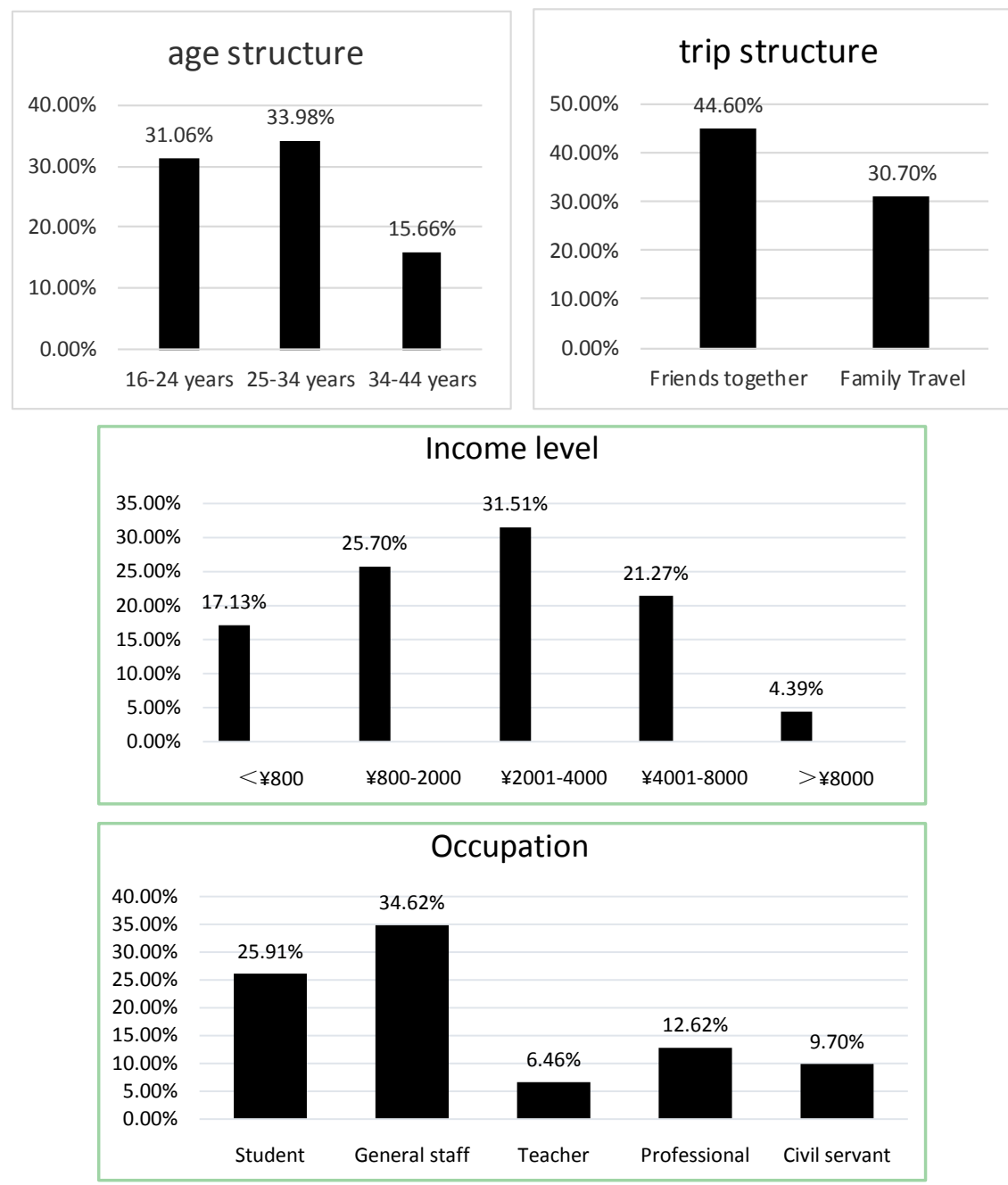

Figure 1. Tourists demographic characteristics. 
Tourism motive is based on the product attributes of the tourist destination and the self After the evaluation of the behavior. According to the survey results (Table 1): which accounted for $42.06 \%$ for the purpose of viewing scenery, secondly is sports and leisure, accounting for $29.15 \%$ and $17.71 \%$. Photography accounted for $8.11 \%$, other tourism motive only $2.97 \%$ (mainly including health care, research visits, business training, etc.). Due to the forest park belongs to the scenic spot, so different from the general sports venues. The eco-sports tourists in the forest park may have dual motive driving on the purpose of traveling. There are not only taking the eco-sports tourism but also taking as watch the scenery as the main motive. Indicating that the forest park tourists motives are not limited to the traditional sightseeing. Eco-sports tourism as the motivation of tourists become more and more. This is derived from scenic beauty, pleasant environment, people experience the strong demand for eco-sports tourism growing.

\subsubsection{Travel Mode}

From the way to travel (Table 2), choose the package tour the most way to travel is $46.02 \%$, it is $28.21 \%$ by car, while the choice of unit organizations under the collective tourism at least, only $12.67 \%$, in addition, there are $13.10 \%$ of the visitors are traveling in the form of non-driving self-help travel. It shows that Liuxi river Forest Park is located in the suburbs, with complex terrain and inconvenient transportation. Based on the tourists basic personal characteristics analysis, career structure and income level become two important factors influencing travel patterns, and development trends for tourists. One is self-Is the package tour, the second is package tour. The travel way is affected by the objective environment and personal factors. Eco-sports tourists choose which kind of transport or form is affected by integrated factors.

As tourism consumption level improved, "Self-driving travelling" has become a new way of urban residents travel, urban tourism consumers away from the hustle and bustle of the city, the pursuit of natural leisure life desire is particularly strong. The eco-sport tourism travel way rise, use the car to peri-urban areas at weekend leisure time (Yin Yumei, Lu Yuqi, \& Deng Jitao, 2004). City

Table 1. Tourists travel behavior motivation results.

\begin{tabular}{cccccc}
\hline $\begin{array}{c}\text { Travel } \\
\text { motive }\end{array}$ & $\begin{array}{c}\text { Ornamental } \\
\text { scenery }\end{array}$ & Vacation & $\begin{array}{c}\text { Sports and leisure } \\
\text { (outdoor) }\end{array}$ & Photography & Other \\
\hline Number & 114 & 48 & 79 & 22 & 8 \\
Percentage & $42.06 \%$ & $17.71 \%$ & $29.15 \%$ & $8.11 \%$ & $2.97 \%$ \\
\hline
\end{tabular}

Table 2. Tourists traveling behaviors characteristics of statistical results.

\begin{tabular}{ccccc}
\hline $\begin{array}{c}\text { Transport } \\
\text { patter }\end{array}$ & $\begin{array}{c}\text { Self-driving } \\
\text { tours }\end{array}$ & $\begin{array}{c}\text { Package } \\
\text { tour }\end{array}$ & Collective organization & $\begin{array}{c}\text { Self-driving tour } \\
\text { not car }\end{array}$ \\
\hline Number & 76 & 125 & 34 & 36 \\
Percentage & $28.21 \%$ & $46.02 \%$ & $12.67 \%$ & $13.10 \%$ \\
\hline
\end{tabular}


suburban forest park just to cater for the need of the eco-sports tourism tourists.

\subsubsection{Willingness to Pay}

According to Table 3 results show that $85.99 \%$ of eco-sports tourists are willing to pay extra expenses for sports activities, eco-sports tourism demand. The willingness to pay (WTP) is based on the acceptable range of product price or service purchased by the visitor. When the level price exceeds the psychological expectations, also known as the payment tolerance, even though level of product service is high also won't choose (Lin Ling, 2013). According to the eco-sports tourism demand of tourists, this paper using multiple linear regression analyzes the relationship between the willingness to pay and the factors of the extra cost (non-scenic ticket) by eco-sports tourists. The following model is used to calculate the WTP expectation of the average willingness to pay for visitors without considering the basic characteristics of the visitor:

$$
W T P=\sum_{i} p_{i} v_{i}
$$

However, in the actual verification of visitors' willingness to pay, they will be affected by age, educational level, income and occupation. The expectation value of $W T P$ is estimated by using multiple linear regression equation. Assuming the relationship between the basic characteristic attribute variables of eco-sports tourists and WTP expectation is Normal distribution (Shi Ling, Ma Wei, Sun Yujun, Zhu Xi, \& Yan Zhongqiang, 2014). The following formula can be used to explain and estimate the range of willingness to pay for visitors:

$$
\operatorname{In}(W T P)=X \alpha+u
$$

Convert to linear:

$$
E(W T P)=X \alpha+\frac{1}{2} \beta^{2}
$$

In the formula, $X$ is the basic characteristic attribute of the visitor, and is the variable coefficient, and follows the random variable of normal distribution.

\subsection{Ecological Sports Tourism Consumption Characteristics}

According to Table 4: the overall consumption level of tourists in the ecological sports tourism project is not high, mainly concentrated in the following $¥ 100$, to be $63.2 \%$; followed by the $¥ 100-300$ is to be $26.5 \%$, more than $¥ 500$ only $10.3 \%$. In the ecological sports tourism consumption project, spend the first five items: "the ball field", "three Ya Tang Valley Adventure", "rowing" and "Orienteering", "grips the raft". Selected 20 tourists in the five kinds of ecological sports tourism project to interview, which $65 \%$ of the visitors think "ecological sports tourism

Table 3. Ecological sports tourism tourists pay will feature statistical results.

\begin{tabular}{cccc}
\hline Willingness to pay & unwilling to pa & uncertainty & Willing to pay extra for sports \\
\hline Number & 22 & 16 & 233 \\
Percentage & $8.11 \%$ & $5.90 \%$ & $85.99 \%$ \\
\hline
\end{tabular}


Table 4. Tourists ecological sports tourism project consumption characteristics of statistical.

\begin{tabular}{cccc}
\hline level of consumption & Under $¥ 10$ & $¥ 100-300$ & Exceed $¥ 500$ \\
\hline Number & 171 & 72 & 28 \\
Percentage & $63.2 \%$ & $26.5 \%$ & $10.3 \%$
\end{tabular}

project experience is strong, worthy of play", $20 \%$ of the visitors think "ecological sports tourism project nothing special, only $15 \%$ of the tourists think" ecological sports tourism project is not fun. On the whole, Eco-sports tourism tourists interest is higher. In the Li Kete five subscales for "project importance" of Liuxi river Forest Park tourists, there are 91 people choose 3 points, 83 people chose 4,19 people choose 5 points, survey data show that exceed 3 points accounted for $71.22 \%$.

Most visitors think it is necessary to develop forest park project. Good project experience can push visitors get a higher degree of satisfaction. The satisfaction of virtuous cycle can inspires scenic area, step up efforts to develop. Tourists have a strong need for Eco sports tourism in Forest Park, but the problems of sports tourism project homogenization and aging, lead to tourists spending is not high in the characteristics of ecological sports tourism project.

\subsection{Ecological Sports Tourism Tourists Perception Characteristics}

\subsubsection{Tourism Destination Attractiveness Analysis}

Tourism destination attraction is an important competitiveness factor, Liuxi river Forest Park have the perfect space, with its unique hydrological resources and forest resources for the ecological sports tourists. Ercan Sirakava et. Definition of ecological sports tourism from the supply perspective, that ecological sports tourism is a kind of non expendable, non competitive, new tourism education and exploration, in the beautiful natural scenery, cultural and historical significance of human civilization and less prominent in areas of human health sports activities (Dimitrios, 2000). It shows that Forest Park has the value of sports leisure and sports entertainment for the ecological sports tourists.

The survey results showed that: the most popular ecological sports tourism project is the "outdoor sports development base", the project is highest visit rate in the ecological sports event in Forest Park reached 36.5\%, this is mainly because the project covers the amphibious outdoor activities, both sport interesting and practicalness, in the five spending projects of ecological sports tourism, there are four part of outdoor sports development base, such as: colour Gun battle, orienteering, rowing and tie the raft. The main visitors is enterprise staff, schools and business unit. because the majority of sports tourism projects belong the team activities, be suited to building team and outdoor quality development, become the star tourism products in Liuxi river Forest Park; lakeside hiking and riding around the island is also popular with tourists, visiting rate is $20.4 \%$. The second is the Monkey Island Scenic Area and National Park, it is 14.5\% and 
$18.9 \%$ respectively, the national customs scenic characteristics is not strong, show the exotic culture of the region, rather than the Conghua local ethnic customs; performers lack of initiative and enthusiasm for show, and most tourists lack of desire. In addition, tourists visiting rate is low because tour time limit and low expectations; The Monkey Island as a result of the interaction is good, be welcomed by family visitors, especially children. But animal management have safety risks and cattered of Monkey Island, influence on visitors safety satisfaction in the scenic area. The botanical garden scenic tourists visiting rate is only $9.7 \%$, this is mainly because the plant science education as with others, enthusiasm and experience is not high in the scenic spot.

\subsubsection{Ecological Sports Tourism Satisfaction}

In order to further analyze the behavior characteristics of tourists, 16 factors were extracted to try to analyze the satisfaction of the tourists in Forest Park ecological sports tourism, and the factor analysis. KMO value of 0.845 , suitable for factor analysis, as shown in Table 5.

According to Table 5 shows that the extracted 4 main factors, the cumulative variance factor contribution rate of $72.361 \%$, according to the 4 common factor variance contribution rate of "ecological environment", "ecological sports tourism facilities", "eco cultural conditions" and "ecological sports tourism service".

Table 5. Factor analysis results.

\begin{tabular}{|c|c|c|c|c|}
\hline $\begin{array}{l}\text { common } \\
\text { factor }\end{array}$ & $\begin{array}{c}\text { Variance } \\
\text { contribution rate }\end{array}$ & Satisfaction index & $\begin{array}{c}\text { Satisfaction } \\
\text { mean }\end{array}$ & Factor load \\
\hline \multirow{4}{*}{$\begin{array}{c}\text { Eco-sports } \\
\text { tourism } \\
\text { facilities }\end{array}$} & \multirow{4}{*}{18.433} & Scenic traffic & 3.96 & 0.657 \\
\hline & & Sports and leisure projects & 4.05 & 0.755 \\
\hline & & Hotels and restaurants & 3.99 & 0.712 \\
\hline & & Entertainment and shopping & 4.02 & 0.649 \\
\hline \multirow{4}{*}{$\begin{array}{c}\text { Ecological } \\
\text { environment }\end{array}$} & \multirow{4}{*}{18.871} & ecological condition & 4.01 & 0.688 \\
\hline & & Water quality & 4.00 & 0.711 \\
\hline & & Forest protection & 4.06 & 0.734 \\
\hline & & air quality & 3.99 & 0.625 \\
\hline \multirow{4}{*}{$\begin{array}{c}\text { Ecological and } \\
\text { cultural } \\
\text { conditions }\end{array}$} & \multirow{4}{*}{17.605} & Local residents attitude & 4.00 & 0.643 \\
\hline & & Scenic management & 3.95 & 0.601 \\
\hline & & Scenic propaganda efforts & 3.98 & 0.713 \\
\hline & & Guide service quality & 4.01 & 0.746 \\
\hline \multirow{4}{*}{$\begin{array}{c}\text { Eco-sports } \\
\text { services }\end{array}$} & \multirow{4}{*}{17.452} & Tourism safety facilities & 4.01 & 0.672 \\
\hline & & Travel safety advice & 3.91 & 0.527 \\
\hline & & Travel safety attitude & 3.97 & 0.651 \\
\hline & & Tourism safety system & 3.94 & 0.497 \\
\hline
\end{tabular}


In the "ecological environment" indicators, "forest protection" satisfaction reached 4.06, is also the 16 highest satisfaction factor value; in the "ecological sports tourism facilities" factors in "sports leisure project" the highest satisfaction reached 4.05, the lowest value is "hotel and restaurant" was 3.99; the second is "human resources" and "ecological ecological sports tourism service". Liuxihe Forest Park "ecological environment" indicators to highlight, provide natural high-quality environment for the development of sports tourism ecology; it is worth noting that the "sports leisure project" indicators of tourist satisfaction reached 4.05, indicating that the tourists of tourism project of ecological sports entertainment, sports fun adventure, the quality of service and other aspects of the establishment of good satisfaction.

Ecological sports tourism tourists satisfaction is better of sports leisure items, but "hotel and catering" tourists satisfaction index is not good enough. According the survey report shows that most respondents are backpack Travelling and tourist groups, traffic is riding, hiking, leasing vehicles, package tour. "Self driving tour" ecological sports tourism tourists have good satisfied with "farm dishes" and "farmhouse enjoyment". The causes of tourist satisfaction differences is authentic catering and hotel facilities are mainly distributed in the scenic area, scenic areas within the food and beverage taste in general, dishes homogenization, resulting in the ecological sports tourism tourists satisfaction lower part. "Water quality" and "ecological environment" two indicators more than 4. This shows that the Forest Park greening rate, vegetation rate, as well as air, water quality and other comprehensive indicators is high of tourist satisfaction. This is a beautiful scenery, pleasant environment, suitable for ecological sports tourism environment for ecological sports tourists. But there is also an ecological sports tourism security system is not perfect, in which the "tourism safety advisory" index is at last in the 16 indicators, it is 3.91. The tourism security is not perfect, Scenic area set up relief stations for one and only simple security warning signs to reply. Ecological sports tourists like adventure, adventure. But sports tourism is adventurous, challenging and complexity. The Forest Park have complex terrain and broad lake. Tourists will worry about something in the tour. Satisfaction of ecological sports tourism safety index is affected. Both ecological sports facilities and ecological environment index satisfaction are better, ecological cultural conditions and ecological sports service are both low.

\section{Conclusion and Suggestions}

\subsection{Conclusion}

The level of consumption of eco-sports tourists in Liuxi river Forest Park is low. This is result from tourists "occupations and destinations attractive. Students, ordinary staff and teachers are mainly visitors. Their income level is mediummiddle group. The proportion of tourists" monthly income is less than $4000 \mathrm{yu}$ an, which is $74.34 \%$. The level of tourists directly affect the level of ecological tourism consumption level; Secondly, Shimen Forest Park, Nankun Mountain Cross Water Resort and other natural scenery excellent forest park are in sur- 
rounding area. Liuxi River Forest Park Destination is less attractive and has higher substitutes.

Liuxi river Forest Park eco-sports tourists sports leisure motivation is obvious, in the "viewing landscape" and "sports leisure" two indicators, even the twofactor motive actuate, in the single selection. There are still $29.15 \%$ select the sports leisure motivation, reflect sports leisure motive is important to eco-sports tourists. The factor analysis shows that the satisfaction of the eco-sports tourists in the Liuxi river Forest Park is higher and the overall satisfaction is 3.99.

What is most concern of the four main factors that in turn as "natural resource conditions", "ecological sports tourism infrastructure", "human resources conditions" and "ecological sports tourism safety". In the secondary indicators, "forest protection" is the highest satisfaction, secondly is "sports and leisure projects". "Travel safety consulting" satisfaction is the lowest.

\subsection{Suggestions}

First, according to the students and ordinary staff as the main force of the source market characteristics, scenic tourists focus on the exploratory, experienced young tourists, to carry out affordable, rich content and sports eco-tourism projects. Such as forest field, forest oxygen bar, forest adventure, cross country riding, jungle crossing, jungle upstream, camping, boating and horse riding and other sports and leisure projects.

Second, strengthen the forest park mountain aesthetic construction between sports leisure and sports competition.

Set up riding and ornamental creatures, configure the tour guide to explain different animal and plant, breaking the traditional botanical garden tour mode. Make visitors study in ecological animal, plant knowledge and playing. Second, to enhance the ecological sports tourism safety satisfaction will help the comprehensive construction of the scenic area, ecological sports tourism project has challenge and interesting. Provide good security services for tourists need to: improve the security knowledge in the scenic spot, build tourists reliable sports tourism environment and facilities.

Third, pay attention to build the forest park eco-sports tourism theme and the shape of tourism. Liuxi River Forest Park has a unique forest natural landscape and animal diversity, with congenital ecological environment advantages, focus on creating eco-sports tourism, sports special tourism as the theme of tourism products in future (Chen et al., 2010). Scenic tourists have high requirements with richness and innovative of tourism products. So need to energetically promote ecological sports, increase media influence in the tourism destination image. On other side, import tourism, sports, food and other subjects of variety shows. add forest park attention.

\section{References}

Chen Ke, Li Zhaoxuan, Wang Qiubing, Zhou Rongwei, \& Wu Ke 陈珂, 李兆轩, 王秋 兵, 周荣伟, 吴可 (2010). Analysis of Tourists' Characteristics and Tourism Consump- 
tion Factors in Tianhua Mountain Forest Park 天华山森林公园游客特征及旅游消费 影响因子分析. Economic Research Guide, No. 11, 112-116.

Chen Lili, \& Zhang Jiaen 陈丽丽, 章家恩 (2011). Liuxi River National Forest Park Tourists Behavior Characteristics and the Source Market Segmentation Research 流溪 河国家森林公园旅游者行为特征及客源市场细分研究. Journal of Anhui Agricultural Sciences, 39, 7983-7985.

Dimitrios, B. (2000). Marketing the Competitive Destination of the Future. Tourism Management, 21, 97-116.

Guoxiao Ping, Li Yiquan, Niu Lijun et al. 谷晓萍, 李岩泉, 牛丽君, 等 (2015). Benxi Guanmenshan National Forest Park Tourists Behavior Characteristics 本溪关门山国 家森林公园游客行为特征. Acta Ecologica, 35, 204-211.

Lin Ling 林玲 (2013). Tourist Attractions Ticket Prices Tourists Willingness to Pay and Its Influence Factors 旅游景区门票价格游客支付意愿与其影响因素的关系研究. Jinan University Master's Degree Thesis, 6-7.

Shi Ling, Ma Wei, Sun Yujun, Zhu Xi, \& Yan Zhongqiang 石玲, 马炜, 孙玉军, 朱䂀, 晏中强 (2014). Evaluation of Economic Value of Ecological Compensation Based on Willingness of Tourist Payment-Taking Su Shan Temple National Forest Park as an Example 基于游客支付意愿的生态补偿经济价值评估-—以武汉素山寺国家森林 公园为例. Resources and Environment in The Yangtze Basin, 23, 180-188.

Yin Yumei, Lu Yuqi, \& Deng Jitao 尹贻梅, 陆玉麒, 邓机涛 (2004). Review of Domestic Tourism Spatial Structure 国内旅游空间结构研究述评. Tourism Science, No. 3, 4954.

Zheng Xiaoxiang 郑晓祥 (2005). The Connotation and Characteristics of Ecological Sports 生态体育的内涵与特点. Journal of Chengdu Sport University, 43-46.

Zhu Zhi 朱智 (2015). Survey and Analysis of Tourists' Satisfaction in Hailuogou National Forest Park 海螺沟国家森林公园游客满意度调查分析. Fujian Forestry Science and Technology, 42, 203-204.

\section{Submit or recommend next manuscript to SCIRP and we will provide best service for you:}

Accepting pre-submission inquiries through Email, Facebook, LinkedIn, Twitter, etc. A wide selection of journals (inclusive of 9 subjects, more than 200 journals) Providing 24-hour high-quality service User-friendly online submission system Fair and swift peer-review system Efficient typesetting and proofreading procedure Display of the result of downloads and visits, as well as the number of cited articles Maximum dissemination of your research work

Submit your manuscript at: http://papersubmission.scirp.org/ Or contact chnstd@scirp.org 